\title{
HIV infection and the esophagus
}

\author{
LINDA RABENECK, MD
}

\begin{abstract}
The esophagus can be involved in human immune deficiency virus (HIV) infection. Esophageal ulcers can occur as part of an acute (primary) HIV infection syndrome. In addition, the esophagus can be involved with the neoplasms associated with acquired immune deficiency syndrome (AIDS) - both Kaposi's sarcoma and non-Hodgkin's lymphoma. Opportunistic infections may also involve the esophagus, most commonly candida and cytomegalovirus infection. It is important for gastroenterologists to be aware of the clinical features of these lesions and to be ready to carry out endoscopy to diagnose these lesions correctly. Can J Gastroenterol $1989 ; 3(1): 1-6$
\end{abstract}

Key Words: Acquired immune deficiency syndrome(AIDS), Esophageal ulcers, Esophagus, Human immunodeficiency virus (HIV)

\section{L'infection à VIH et l'oesophage}

RESUME: L'oesophage de l'être humain infecté par le virus d'immunodéficience humaine (VIH) peut aussi être touché. Des ulcères de l'oesophage peuvent se produire dans le cadre du syndrome aigu (primaire) d'infection à VIH. De plus, il peut être atteint de néoplasmes secondaires au syndrome d'immunodéficience acquise (SIDA), tels le sarcome de Kaposi et les lymphomes non-Hodgkin. Les germes opportunistes peuvent également attaquer l'oesophage - les candida et le virus cytomégalique surtout. Il est important que les gastroentérologues reconnaissent les caractéristiques cliniques de ces lésions et soient prêts à pratiquer une endoscopie afin de les diagnostiquer correctement.

University of British Columbia, St Paul's Hospital, Vancouver, British Columbia

Correspondence and reprints: Dr Linda Rabeneck, Yale University School of Medicine, Clinical Scholars Program, Room IE, SHM, 333 Cedar Street, New Haven, CT 06510-8025, USA

Received for publication May 16, 1988. Accepted May 19, 1988
HE CENTER FOR DISEASE CONTROL
(CDC) first reported cases of the acquired immune deficiency syndrome (AIDS) in $1981(1,2)$. The cause of AIDS is a human retrovirus, first named human T-cell lymphotropic virus (HTLVIII) $(3,4)$ or lymphadenopathy associated virus (LAV) (5), subsequently renamed human immunodeficiency virus (HIV) (6).

Infection with HIV over a period of time results in a variety of immunologic defects, the most critical of which is depletion of T-helper cells, which in turn leads to the development of opportunistic infections, Kaposi's sarcoma and lymphoid malignancies (7). It is the presence of these specific opportunistic infections and malignancies in an HIV infected individual which establishes a diagnosis of AIDS, as defined by the CDC $(8,9)$.

The gastrointestinal tract is a major target organ for involvement in AIDS (10). The esophagus is of particular interest as it can be involved not only with a number of the opportunistic infections and malignancies of AIDS but also at the 
onset of HIV infection. This paper reviews the clinical features of the esophageal lesions associated with HIV infection.

\section{ACUTE (PRIMARY) HIV INFECTION}

Current evidence suggests that, following exposure to HIV, most individuals who seroconvert (ie, who develop antibodies to HIV) experience no symptoms (11). However, a number of individuals do experience a clinical illness; certain specific clinical syndromes have been described. The first of these syndromes to be recognized was that of an acute mononucleosis-like illness. The clinical features of this illness include fever, chills, night sweats, malaise, myalgia, arthralgis, sore throat, lymphadenopathy and skin rash $(12,13)$. Other syndromes subsequently recognized to occur in association with acute HIV infection include acute meningitis (14), acute encephalitis (15), acute polyneuropathy (16) and acute brachial neuritis (17).

It is now clear that acute HIV infection may cause an illness characterized by the presence of unusual esophageal ulcers. The features of this illness, occurring in a series of homosexual men, seen

TABLE 1

Classification system for human T-lymphotropic virus type III/lymphadenopathy associated virus infection

\begin{tabular}{ll}
\hline Group I & Acute infection \\
Group II & Asymptomatic infection \\
Group III & Persistent generalized lymphadenopathy \\
Group IV & Other disease \\
Subgroup A & Constitutional disease \\
Subgroup B & Neurologic disease \\
Subgroup C & Secondary infectious diseases \\
Category C-1 & Specified secondary infectious diseases listed in the CDC \\
& surveillance definition for AIDS \\
Category C-2 & Other specified secondary infectious diseases \\
Subgroup D & Secondary cancers \\
Subgroup E & Other conditions \\
\hline
\end{tabular}

- Includes those patients whose clinical presentation fulfills the definition of the acquired immune deficiency syndrome(AIDS) used by CDC for national reporting

in Vancouver between 1982 and 1984, were described at the Canadian Society for Clinical Investigation meeting in September 1987 (18). Thirteen homosexual men presented with odynophagia, 11 also had a maculopapular skin rash and three had ulcers on the hard palate. Esophagogastroduodenoscopy revealed the presence of multiple discrete ulcers measuring 0.3 to $1.5 \mathrm{~cm}$ in diameter in the esophagus (Figures 1,2). HIV serology carried out by Western blot technique demonstrated seroconversion.
Electron microscopic examination of biopsy specimens taken from the margins of the esophageal ulcers revealed the presence of virus-like particles 120 to 160 $\mathrm{mm}$ in diameter, with morphologic features consistent with retroviruses. In all men the acute illness was self-limited; the rash cleared and the esophageal ulcers healed.

Proof of the presence of HIV in the esophageal tissue requires further study. However, the description of this syndrome extends knowledge of acute HIV

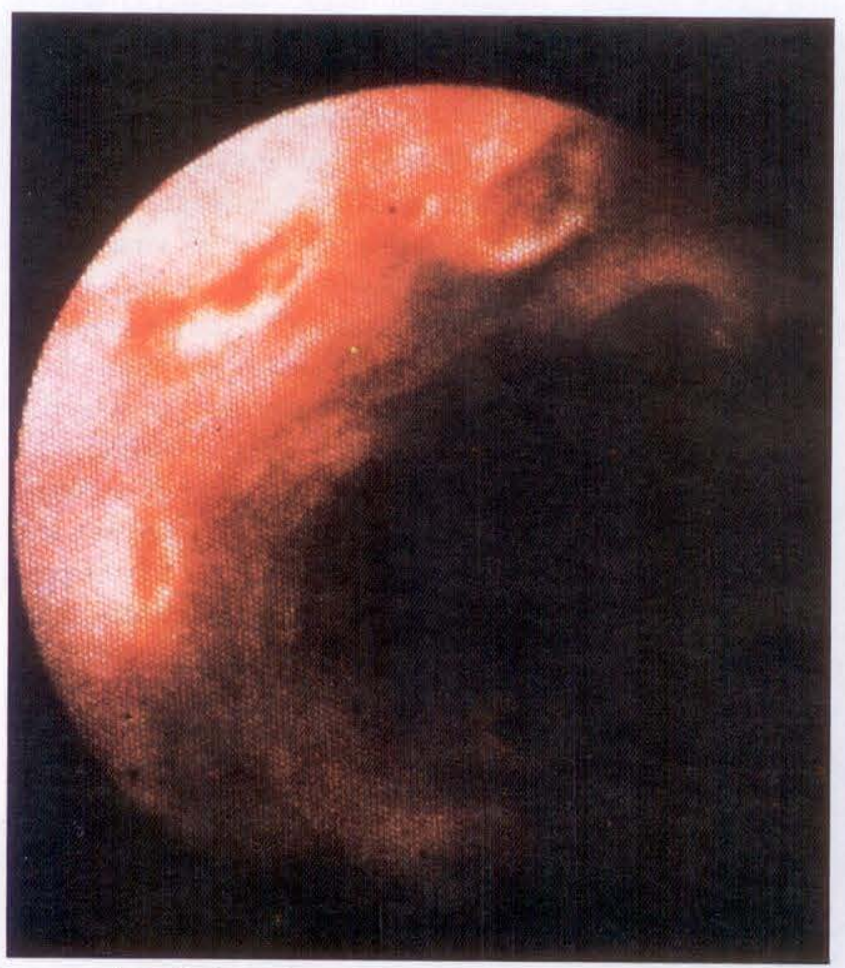

Figure 1) Multiple esophageal ulcers measuring 0.5 to $1 \mathrm{~cm}$ in diameter in an individual with primary HIV infection

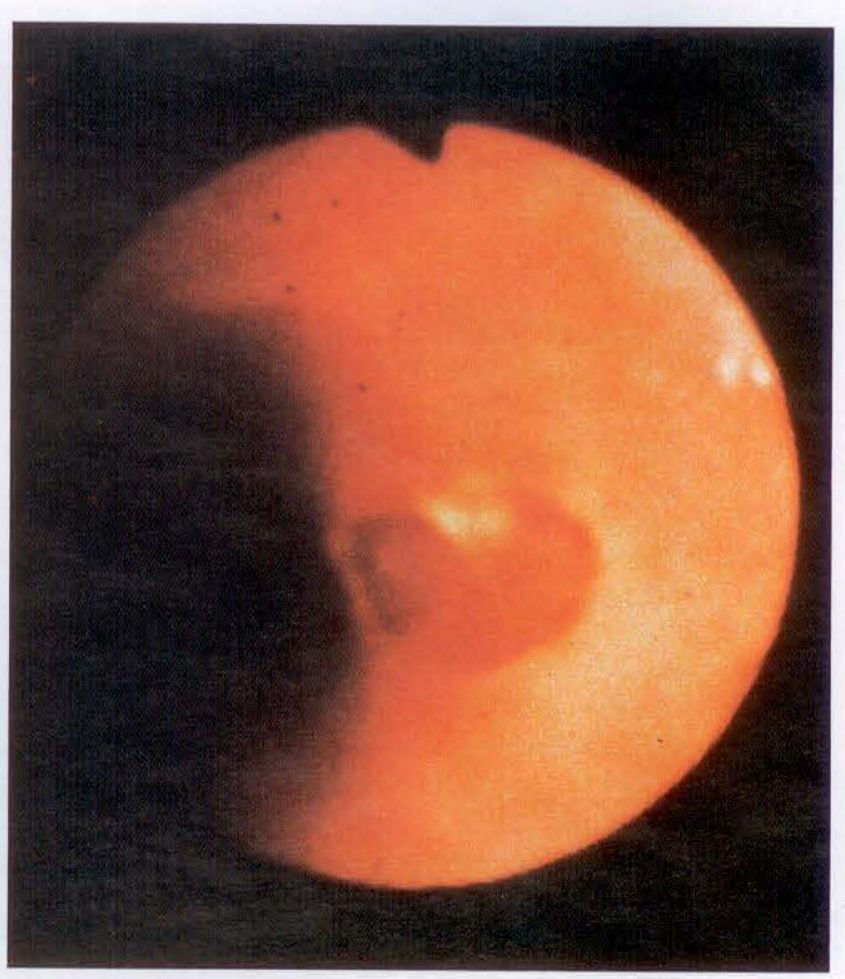

Figure 2) Discrete single esophageal ulcer, $1.5 \mathrm{~cm}$ long and $1 \mathrm{~cm}$ wide in an individual with primary HIV infection 


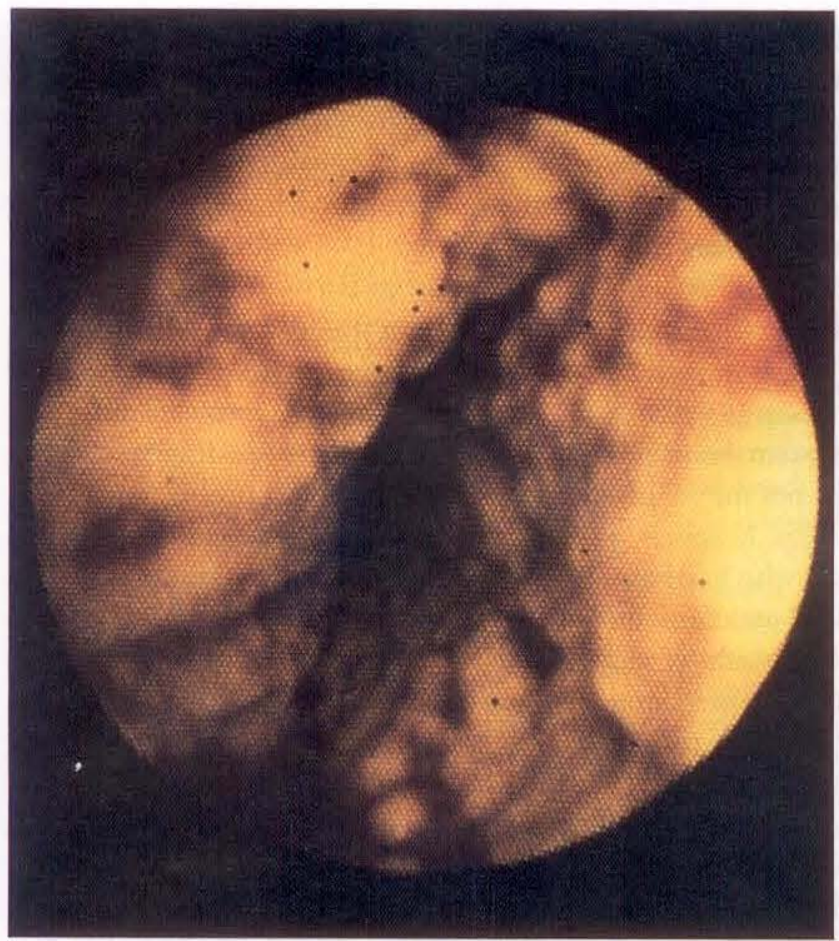

Figure 3) Esophageal candida in a man with AIDS: Confluent raised white plaques in the esophagus

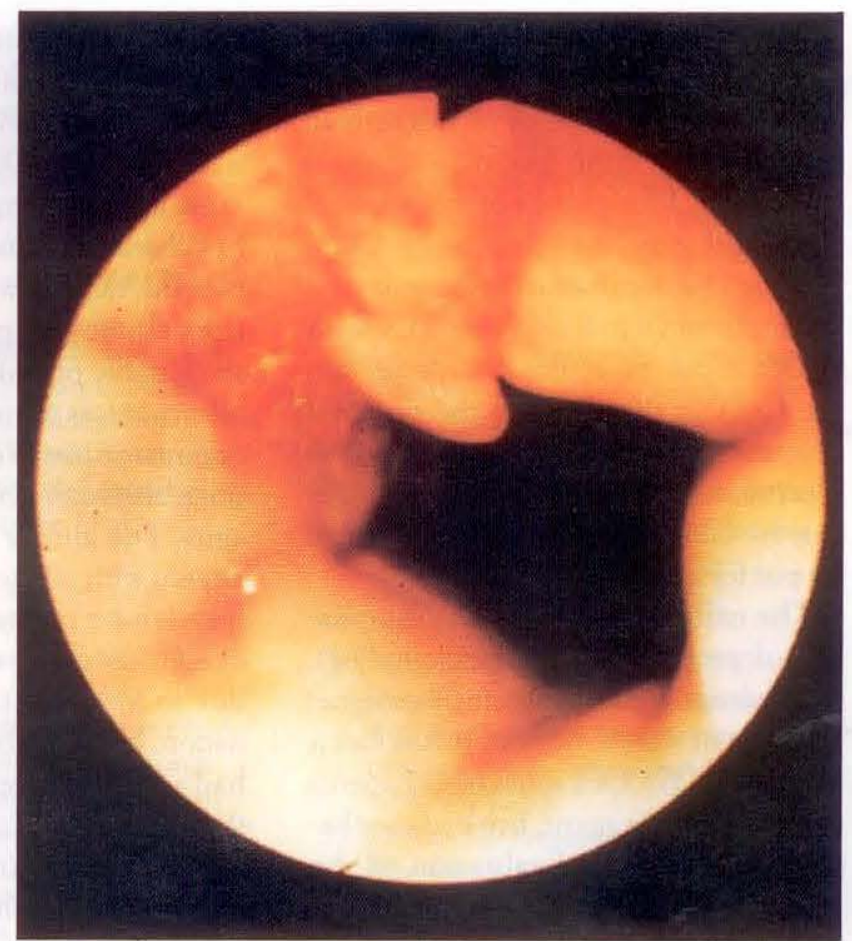

Figure 4) CMV associated esophageal ulcer with irregular margins, measuring $3 \mathrm{~cm}$ in length and $1.5 \mathrm{~cm}$ in width in an individual with AIDS syndromes and suggests that esophageal cells may be a target for HIV infection.

\section{ESOPHAGEAL LESIONS IN AIDS}

AIDS can be considered one of the chronic sequelae of HIV infection. As discussed previously the CDC has defined and classified AIDS (Table 1) (9). As far as the gastrointestinal tract is concerned, the CDC has defined specific opportunistic infections (group IV, category C-1) and specific neoplasms (group IV, category C-2) which fulfill the definition of AIDS.

Esophageal candida: Esophageal candida is one of the most common opportunistic infections in $\operatorname{AIDS}(10,19)$. A patient with esophageal candida may complain of dysphagia or, less commonly, odynophagia. Some complain only of heartburn or of anorexia, while others report no symptoms. While some observers have argued that the presence of oral candida is predictive of the presence of esophageal candida (20), this is not necessarily so; in HIV infected individuals, esophageal candida can be present in the absence of oral candida and vice versa.

It is important to endoscope individuals at risk for AIDS who present with symptoms suggestive of esophageal candida. The reasons for this are: there are other possible causes of dysphagia and odynophagia in such persons besides esophageal candida; and the finding of esophageal candida in an HIV infected individual establishes a diagnosis of AIDS. The latter is crucial information which the individual and the physician deserve to know.

At endoscopy the lesion is characterized by the presence of raised white plaques which may be confluent (Figure 3). Endoscopic biopsies reveal the presence of budding particles and hyphae; findings which are consistent with the diagnosis. Fungal cultures can be obtained if positive identification of the fungus is desired. A recent report of white plaques and esophageal ulcers in an AIDS patient was attributed to Torulopsis glabrata, a related fungus (21).

While mycostatin oral solution controls oral candida, often it is ineffective therapy for esophageal candida. Ketoconazole at a dose of $200 \mathrm{mg}$ by mouth once daily can be effective (22), although there are reports of esophageal candida refractory to this therapy (23) and the agent can cause hepatocellular necrosis
(24). In addition, of impor tance to those patients receiving antimycobacterial therapy, ketoconazole can interact with rifampin and isoniazid (25). Amphotericin B therapy has been advised by many (2632). Clotrimazole, however, is effective therapy and avoids the risk of toxicity with amphotericin $B$ as well as the need for parenteral administration. The drug is given as a suppository at a dose of 100 mg by mouth to suck three times daily. The esophageal candida clears in seven to 10 days. Thereafter, the drug can be given in a dose of $100 \mathrm{mg}$ once or twice daily to prevent recurrences (33).

Cytomegalovirus infection (CMV): CMV infection of the esophagus can cause esophageal ulcers. Individuals with CMV-associated esophageal ulcers usually present with odynophagia or constant retrosternal pain. The ulcers may be single and discrete or multiple with normal appearing intervening esophageal mucosa (Figure 4). The ulceration may also be confluent and can mimic peptic esophagitis due to gastroesophageal reflux disease $(34,35)$. A case of a giant $\mathrm{CMV}$-associated esophageal ulcer with extension to the adventitia has been described (36). 
Light microscopic examination of endoscopic mucosal biopsy specimens reveals the presence of characteristic intranuclear and intracytoplasmic inclusion bodies. Viral culture of the inflamed tissue will grow the virus. Since CMV can often be documented in uninflamed gastrointestinal mucosa of patients with AIDS, it can be difficult to be certain the CMV is the cause of the mucosal ulceration. If other causes of mucosal ulceration can be ruled out, a stronger case for CMV as the causative agent can be put forward.

The natural history of CMV esophageal ulcers is not clear. Ganciclovir (9-[1, 3-dihydroxy-2-propoxymethyl] guanine) therapy of CMV infection has been attempted (37). Of a series of 41 patients treated with this agent, five had esophageal involvement. Evaluation of the response to therapy was inconclusive in these patients as follow-up endoscopy was not carried out. Therapy with Foscarnet (phosphonoformate) has also been reported (38).

Herpes simplex virus: Herpes simplex virus can cause chronic perianal ulceration in individuals with AIDS (39). However, there is little published regarding herpes simplex infection of the esophagus in AIDS patients.

Cryptosporidia: Cryptosporidium is the most common protozoan to infect the gastrointestinal tract in AIDS patients. It commonly affects the small bowel or colon and causes diarrhea, which may be secretory in type $(10,40)$. Cryptosporidia have also been observed in gastric mucosa and more recently a case of esophageal cryptosporidiosis was described (41). The patient was a two-yearold girl with AIDS. The patient developed dysphagia; endoscopy showed 'areas of inflammation in the distal esophagus'. Pathological examination of mucosal biopsy tissue revealed the presence of cryptosporidium.

A diagnosis of cryptosporidiosis can be established by demonstrating the presence of the organism in stool using an acid fast stain. Light microscopic examination of mucosal biopsy specimens demonstrating the presence of the organism may also be used to establish the diagnosis. Spiramycin has been reported to be effective therapy for cryptosporidiosis (42); however, this observation requires confirmation.

Mycobacteria: Mycobacterial infection is common in AIDS patients. Overall, the most common mycobacterial isolate is Mycobacterium avium-intracellulare complex (MAIC). However, in AIDS patients from ethnic groups in which tuberculosis is highly prevalent, infection with $M$ tuberculosis is more common (43). Both organisms involve the gastrointestinal tract, although generally not the esophagus. The author has seen, however, a patient with odynophagia who had large hilar lymph nodes and a $2 \mathrm{~cm}$ diameter deep ulcer of the esophagus which was due to MAIC. At post mortem examination, it was established that the patient had a fistula between the esophagus and the mediastinum.

The diagnosis of mycobacterial infection may be established by tissue biopsy. Since granuloma formation has been described as poor and acid fast stains may be negative, culture of tissue specimens is of greatest importance $(44,45)$. When the gastrointestinal tract is involved, stool samples stained with acid fast stain may be positive

The $\mathrm{CDC}$ has issued guidelines for the treatment of mycobacterial diseases in individuals with HIV infection (46). Chemotherapy is advised whenever acid fast bacilli are found in a tissue or fluid specimen. The initial drug regimen should be effective against tuberculosis, eg, isoniazid, rifampin and either ethambutol or pyrazinamide. If the isolate proves to be MAIC, the regimen is switched to isoniazid, ethambutol, ansanmycin and clofazimine. It is recognized that the appropriate duration of therapy for tuberculosis in HIV infection is unknown, in addition, optimal therapy for MAIC is not know. Patients with $M$ tuberculosis and HIV infection tend to respond to therapy whereas those with MAIC do not.

Kaposi's sarcoma: Kaposi's sarcoma is a malignancy which can involve the skin, lymph nodes and other organs in AIDS patients. Approximately $50 \%$ of AIDS patients with skin involvement have visceral involvement with Kaposi's sarcoma (47). The lesions may involve any portion of the gastrointestinal tract from the oral cavity to the anus. Usually Kaposi's sarcoma involving the gastrointestinal tract does not cause symptoms or complications such as bleeding or obstruction (47). Kaposi's sarcoma involving the esophagus, however, may cause dysphagia.

Endoscopy is a more sensitive method than barium studies for documenting the presence of the lesions. The endoscopic appearance is characteristic. The lesions are macules or sessile nodules. The latter may have central umbilication. The colour is usually a red or red-purple and the size varies from several millimetres in width to several centimetres. Because the lesions are submucosal, endoscopic biopsies taken in the usual manner with biopsy forceps may not reach the lesions, hence in practice the diagnosis is often established on the basis of the gross appearance alone.

In patients with Kaposi's sarcoma involving the skin, the finding of gastrointestinal Kaposi's sarcoma is associated with a poorer prognosis. There are chemotherapy regimens for the treatment of Kaposi's sarcoma. The decision to treat is usually left with the oncologist.

Lymphoma: Lymphomas occur less commonly than Kaposi's sarcoma in AIDS patients. Although both nonHodgkin's lymphoma and Hodgkin's lymphoma are reported to occur in association with HIV infection, only nonHodgkin's lymphoma fulfills the CDC criteria for the diagnosis of AIDS (9). In AIDS patients, lymphomas have been reported to occur throughout the gastrointestinal tract. Bernai and del Junco (49) reported the clinical features of four cases of esophageal lymphoma occurring in AIDS patients. Three of the patients reported dysphagia. Endoscopic biopsy of the lesion established the diagnosis, which in each case was a non-Hodgkin's lymphoma.

Esophageal ulcers: Lastly, there may be an additional esophageal lesion in AIDS patients. Such patients present with odynophagia and are found to have discrete esophageal ulcers at endoscopy. In these cases a search for an underlying infectious agent or neoplasm has failed to reveal the cause of the lesions (50). It is possible that these esophageal ulcers are in some way related to those of the acute (primary) HIV infection. 


\section{REFERENCES}

1. Centers for Disease Control.

Pneumocystis pneumonia - Los

Angeles. MMWR 1981:30:250-2.

2. Centers for Disease Control. Kaposi's sarcoma and pneumocystis pneumonia among homosexual men - New York City and California. MMWR 1981;25:305-8.

3. Popovic M, Sarngadharan MG, Read E Gallo RC. Detection, isolation, and continuous production of cytopathic retroviruses (HTLV-III) from patients with AIDS and pre-AIDS. Science 1984;224:497-500.

4. Gallo RC, Salahuddin SZ, Popovic M, et al. Frequent detection and isolation of cytopathic retrovirus (HTLV-III) from patients with AIDS and at risk for AIDS. Science 1984:224:500-3

5. Barre-Sinnousi F, Chermann C, Rey F, et al. Isolation of a T-lymphotropic retrovirus from a patient at risk for acquired immune deficiency syndrome (AIDS). Science 1983;220:868-71.

6. Coffin J, Haase A, Levy JA, et al. Human immunodeficiency viruses. Science 1986;232:697. (Letter)

7. Fauci AS, Masur H, Gelmann EP, Markham PD, Hahn BH, Lane HC. The acquired immunodeficiency syndrome: An update. Ann Intern Med 1985;102:800-13.

8. Centers for Disease Control. Revision of the रेखेse definition of acquired immunodeficiency syndrome for national reporting - United States. MMWR 1985;34:373-5.

9. Centers for Disease Control. Classification system for human T-lymphotropic virus type IIV/ lymphadenopathy-associated virus infections. Ann Intern Med 1986; 105:234-7

10. Gottlieb MS, Groopman JE, Weinstein WM, Fahey JL, Detels R. The acquired immunodeficiency syndrome. Ann Intern Med 1983;99:208-20.

11. Boyko WJ, Schechter MT, Craib KJP, et al. The Vancouver LymphadenopathyAIDS Study: 7. Clinical and laboratory features of 87 cases of primary HIV infection. Can Med Assoc J 1987;137:109-13

12. Anon. Needlestick transmission of HTLV III from a patient infected in Africa. Lancet 1984;ii:1376-7. (Edit)

13. Cooper DA, Gold J, Maclean P, et al. Acute AIDS retrovirus infection: Definition of clinical illness associated with seroconversion. Lancet 1985;: $: 537-40$

14. Ho DD, Rota TR, Schooley RE, et al. Isolation of HTLV III from cerebrospinal fluid and neural tissues of patients with neurologic syndromes related to the acquired immunodeficiency syndrome. N Engl J Med
1985;313:1493-7.

15. Carne CA, Tedder RS, Smith A, et al. Acute encephalopathy coincident with seroconversion for anti-HTLV-III. Lancet $1985 ;$ ii: $1206-8$.

16. Piette AM, Tusseau F, Vignon D, et al. Acute neuropathy coincident with seroconversion for anti-LAV/HTLV-III Lancet 1986;i:852

17. Calabrese LH, Proffitt MR, Levin KH, Yen-Lieberman B, Starkey C. Acute infection with the human immunodeficiency virus (HIV) associated with acute brachial neuritis and exanthematous rash. Ann Intern Med 1987:107:849-51.

18. Rabeneck L, Popovic M, McLean DM, et al. Esophageal ulcers in acute HIV infection. Clin Invest Med 1987;10 (Suppl B):B134.

19. Gottlieb MS, Schroff R, Schanker HM et al. Pneumocystis carinii pneumonia and mucosal candidiasis in previously healthy homosexual men. N Engl J Med 1981:305:1425-31.

20. Tavitian A, Raufman J-P, Rosenthal LE Oral candidiasis as a marker for esophageal candidiasis in the acquired immunodeficiency syndrome. Ann Intern Med 1986; 104:54-5.

21. Tom W, Aaron JS. Esophageal ulcers caused by Torulopsis glabrata in a patient with acquired immune deficiency syndrome. Am J Gastroenterol 1987;82:766-8.

22. Fazio RA, Wicremesinghe $\mathrm{PC}$, Arsura EI Ketoconazole treatment of candida esophagitis - A prospective study of 12 cases. Am J Gastroenterol 1983;78:261-4.

23. Tavitian A, Raufman J-P, Rosenthal LE, Weber CA, Dincsoy HP. Ketoconazoleresistant candida esophagitis in patients with acquired immunodeficiency syndrome. Gastroenterology $1986 ; 90: 443-5$

24. Bercoff E, Bernuau J, Degott C, et al. Ketoconazole-induced fulminant hepatitis. Gut 1985;26:636-8.

25. Englehard D, Stutman HR, Marks MI. Interaction of ketoconazole with rifampin and ixoniazid. N Engl J Med 1984:311:1681-3.

26. Furio MM, Wordell CJ. Treatment of infectious complications of acquired immunodeficiency syndrome. Clin Pharm 1985:4:539-54.

27. Young LS. Treatable aspects of infection due to human immunodeficiency virus. Lancet 1987;ii: 1503-6.

28. Fauci AS, Macher AM, Longo DL, et al. Acquired immunodeficiency syndrome: Epidemiologic, clinical, immunologic and therapeutic considerations. Ann Intern Med 1984:100:92-106.

29. Smith PD. Gastrointestinal infections in patients with acquired immunodeficiency syndrome. Viewpoints Dig Dis $1986 ; 18: 1-4$
30. Shepherd FA, Fanning MM, Duperval $R$, et al. A guide to the investigation and treatment of patients with AIDS and AIDS-related disorders. Can Med Assoc J 1986;134:999-1008

31. Quinn TC. Clinical approach to intestinal infections in homosexual men. Med Clin North Am 1986;70:611-34

32. Lerner CW, Tapper ML. Opportunistic infection complicating acquired immune deficiency syndrome. Medicine 1984;63:155-64.

33. Rabeneck L, St Paul's Hospital AIDS Care Group. Esophageal candidiasis in AIDS patients: Therapy with clotrimazole. Clin Invest Med 1985:8(3):A95

34. Agha FP, Lee HH, Nostrant TT. Herpetic esophagitis: A diagnostic challenge in immunocompromised patients. Am J Gastroenterol 1986;81:246-53.

35. Gertter SL, Pressman J, Price P. Brozinski S, Miya K. Gastrointestinal cytomegalovirus infection in a homosexual man with severe acquired immunodeficiency syndrome. Gastroenterology 1983;85:1403-6

36. St Onge G, Bezahler GH. Giant esophageal ulcer associated with cytomegalovirus. Gastroenterology 1982:83:127-30.

37. Chachoua A, Dieterich D, Krasinski K, et al. 9-(1,3-dihydroxy-2-propoxymethyl) guanine (Ganciclovir) in treatment of cytomegalovirus gastrointestinal disease with the acquired immunodeficiency syndrome. Ann Intern Med 1987; 107:133-7.

38. Weber JN, Thom S, Barrison I, et al. Cytomegalovirus colitis and esophageal ulceration in the context of AIDS: Clinical manifestations and preliminary report of treatment with Foscarnet (phosphonofornate). Gut 1987;28:482-7.

39. Siegal F, Lopez C, Hammer GS, et al. Severe acquired immunodeficiency in male homosexuals, manifested by chronic perianal ulcerative herpes simplex lesions. N Engl J Med 1981;305:1439-44.

40. Andreani T, Modigliani R, LeCharpentier Y, et al. Acquired immunodeficiency with intestinal cryptosporidiosis: Possible transmission by Haitian whole blood. Lancet 1983;i:1187-91.

41. Kazlow PG, Shah K, Benkov KJ, Dische R, LeLeiko NS. Esophageal cryptosporidiosis in a child with acquired immune deficiency syndrome. Gastroenterology 1986;91:1310-3.

42. Portnoy D, Whiteside ME, Buckley E MacLeod CL. Treatment of intestinal cryptosporidiosis with spiramycin. Ann Intern Med 1984:101:202-4

43. Pitchenik AE, Cole C, Russell BW, 
Fischl MA, Spira TJ, Snider DE Tuberculosis, atypical mycobacteriosis, and the acquired immunodeficiency syndrome among Haitian and non-Haitian patients in South Florida. Ann Intern Med 1984;101:641-5.

44. Giron JA, Mandel LJ, Wollschlager C, et al. Mycobacterial culture in acquired immunodeficiency syndrome. Ann Intern Med 1983;98:1028-9.

45. Cohen RJ, Samoszuk MK, Busch D, Lagois M. Occult infections with $M$ intracellulare in bone marrow biopsy specimens from patients with AIDS.
N Engl J Med 1983;308:1475-6.

46. Centers for Disease Control. Diagnosis and management of mycobacterial infection and disease in persons with human immunodeficiency virus infection. Ann Intern Med 1987; 106:254-6.

47. Fiedman SL, Wright TL, Altman DF. Gastrointestinal Kaposi's sarcoma in patients with acquired immunodeficiency syndrome. Gastroenterology 1985;89:102-8.

48. Rose HS, Balthazar EJ, Megibow AJ, Horowitz L, Laubenstein LJ. Alimentary tract involvement in Kaposi s sarcoma. Radiologic and endoscopic findings in 25 homosexual men. Am J Radiol 1982;139:661-6.

49. Bernai A, del Junco GW. Endoscopic and pathologic features of esophageal lymphoma: A report of four cases in patients with acquired immune deficiency syndrome. Gastrointest Endosc 1986;32:96-9.

50. Gaylor RE, Stone EG, Glaser RL, Singleton KB, Crespo JH. Chronic esophageal ulcers in an AIDS patients. Gastrointest Endosc 1986;32:370-1. 


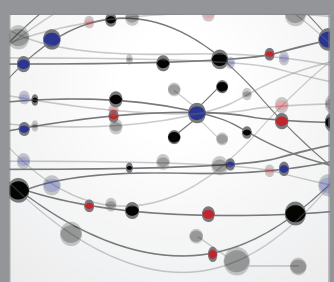

The Scientific World Journal
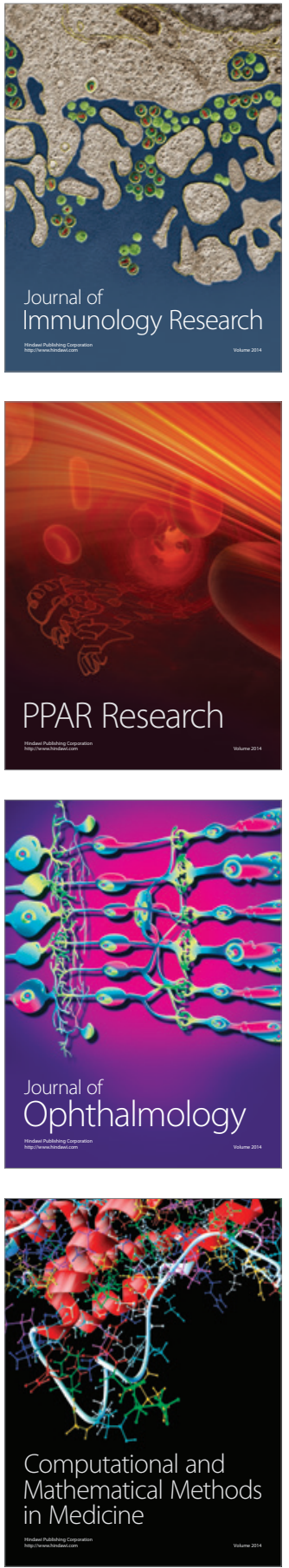

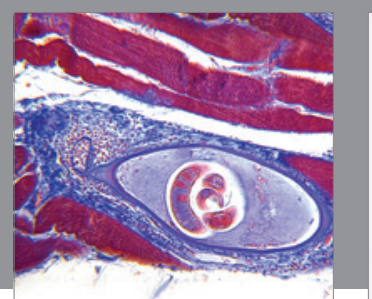

Gastroenterology Research and Practice

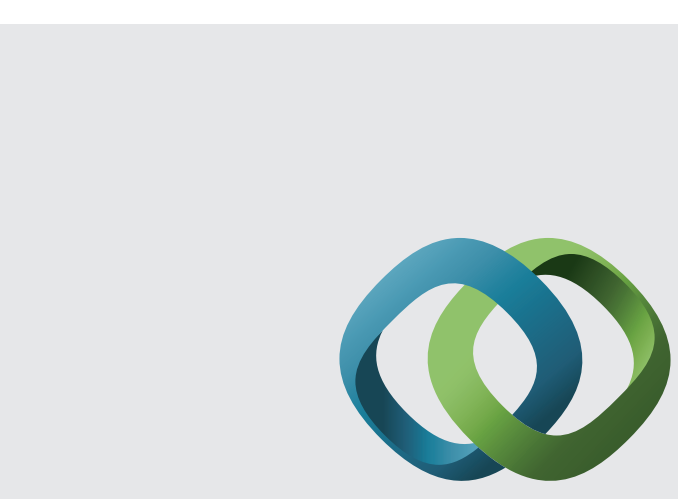

\section{Hindawi}

Submit your manuscripts at

http://www.hindawi.com
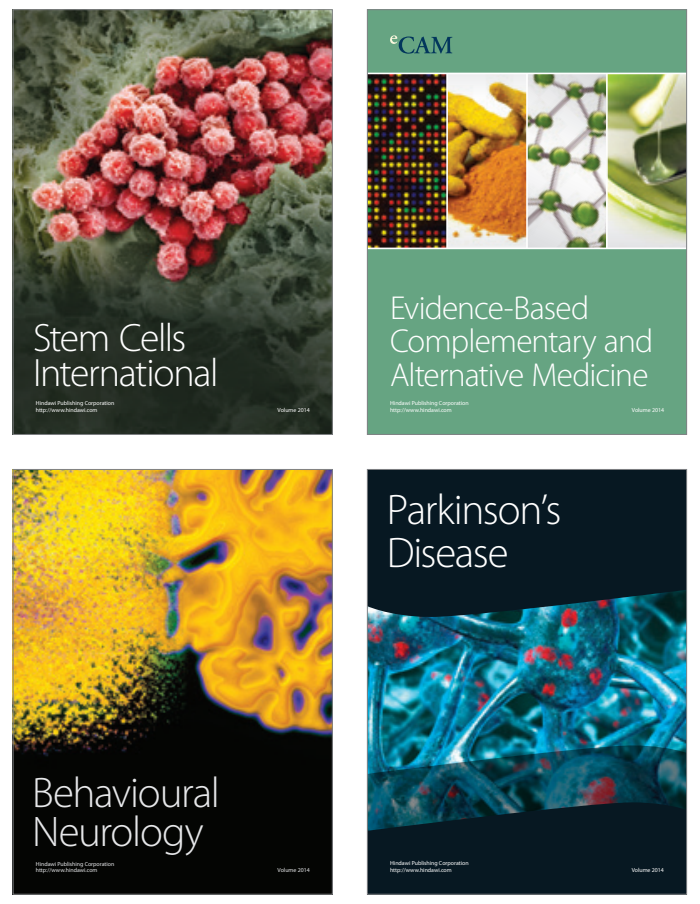
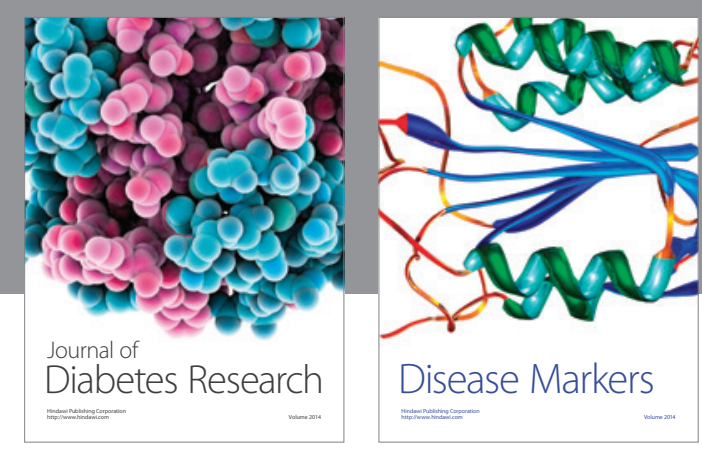

Disease Markers
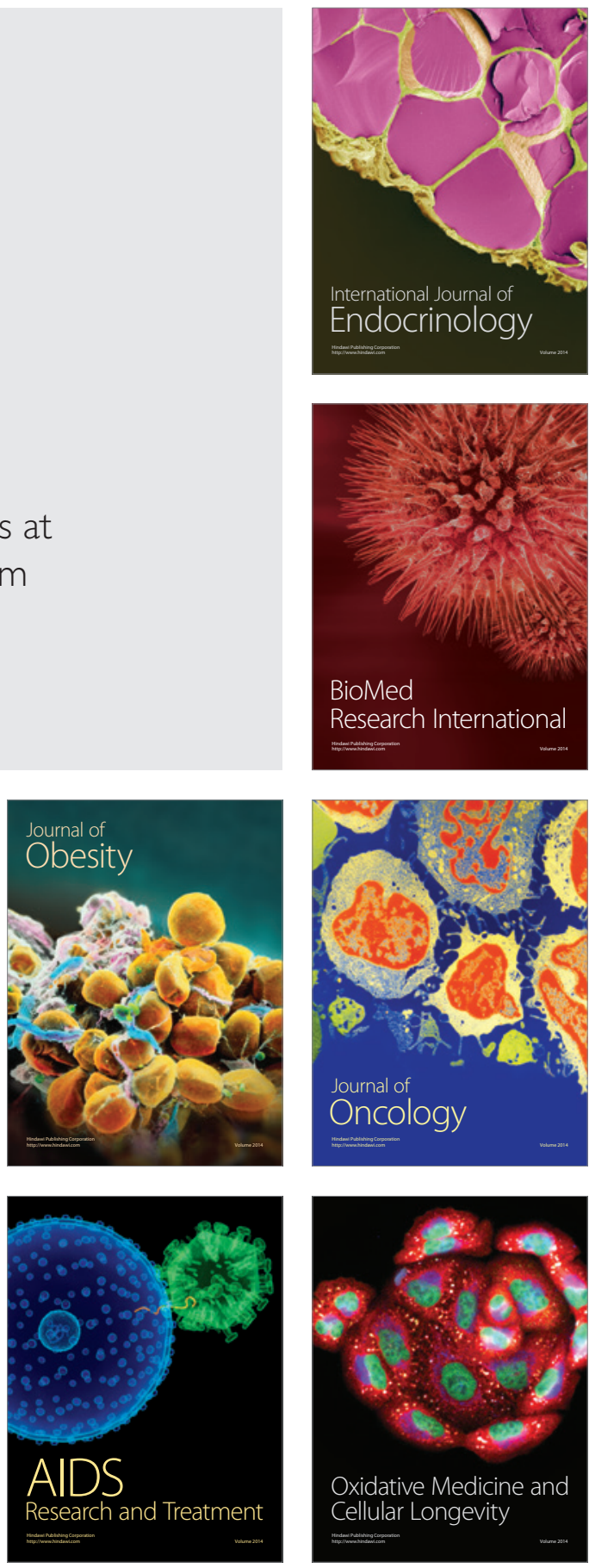